\title{
Research on the Effects of Enterprise- Supplier Information Sharing on Enterprise Innovation Performance
}

\author{
Jiang Xiaorong \\ Economics and Management Department \\ Xi'an University of Technology (XUT) \\ Xi'an, Shannxi Province, China \\ E-mail: jiaoxiangrong99@163.com
}

\author{
Yang Hui \\ Economics and Management Department \\ Xi'an University of Technology (XUT) \\ Xi'an, Shannxi Province,China \\ E-mail: 304926346@qq.com
}

\begin{abstract}
Since 21st Century, Chinese enterprises are faced with severe situation which is rapid technological development, intense competition and personalized customer demand. Chinese enterprises have the only way to adapt to economic globalization and informatization, which is to share the information with suppliers and make full use of information resources, achieving innovation performance steadily. This paper based on the survey of Chinese manufacturer enterprises and the existing research results to propose conceptual model, carrying out the empirical study, and the results show that, (1) the main effect: information sharing of the enterprise and supplier has significant positive influence on communication, trust, commitment and the enterprise innovation performance; communication has significant positive influence on trust and the enterprise innovation performance; trust has significant positive influence on commitment;(2) mediating effect: the mediating communication has a partial mediation effect between enterprise-supplier information sharing and the enterprise innovation performance significantly, but has no significant mediating effect between the information sharing and trust; trust has a significantly mediating effect between information sharing and commitment; commitment has a significantly partial mediating effect between enterprisesupplier information sharing and the enterprise innovation performance. To a certain extent, the conclusion provides the theoretical support to share information between enterprises and suppliers for improving innovation performance of enterprises.
\end{abstract}

Keywords- Information sharing; Innovation performance; Communication; Trust; Commitment

\section{INTRODUCTION}

With the global economic integration and development of global informationization, manufacturing enterprise (Hereinafter referred to as the enterprise) facing the business environment of uncertainty increases gradually and market demand is also increasingly diversified and personalized. In this fierce competition environment driving, enterprise and supplier use advanced information technology to share high quality of valuable information has become the enterprise effective way to improve the innovation performance.
Although the influence on information sharing to innovation performance have been researched by domestic and international scholars, enterprise and supplier information sharing mechanism of effect on enterprise innovation performance is limited, with Chinese manufacturing enterprises as the research object, and communication, trust and commitment as a mediating variable. Therefore, to explore the enterprise and supplier information sharing mechanism of impact on enterprise's innovation performance, so as to provide reasonable suggestions to improve the Chinese manufacturing enterprise innovation performance, it has positive significance in two aspects of theory and practice.

\section{A. Information sharing}

Information quality reflects the potential of enterprise information sharing (Subramaniam and Youndt, 2005).

Studies have showed that, enterprises and suppliers in exchange predictive information can promote the communication between the two sides and increase trust between the two parties. It has a positive impact on innovation performance to supply chain suppliers (already is a partnership) (Forslund and Jonsson, 2007). Jung Young Lee et al. (2011) it is considered to share strategic and operational information between the enterprise and the supplier in order to facilitate the implementation of the enterprise cooperation activities in the supply chain (Moberg et al., 2002). The change of strategic information will not only affect the enterprises, but also affect the supplier management strategy, willing to share the information about their knowledge, expertise, further strengthening the bilateral relations between the two sides. It has a positive role in promoting communication, trust and commitment [1].Levy et al (2001)studied a case to discover that the enterprises keep the competitive advantage through the information system.

Between enterprises and suppliers to take appropriate information technology, it improved the quality of information sharing effectively and convey the information content accurately timely to each other. And it has a positive impact on the innovation through the regulating effect of existing relationship (Chae et al., 2005). In fact, long-term relationship oriented strategy of cooperation, 
network management, information technology progress can promote the communication between enterprises and suppliers (Paulraj et al., 2008). Communication will further help to improve performance including the innovation performance (Hsiu-Chun Cheng and $\mathrm{Mu}-\mathrm{Chen}$ Chen, 2010) [2].

In summary, we put forward the following hypothesis:

H1: Information sharing of enterprise-supplier has positive influence on communication;

$\mathrm{H} 2$ : Information sharing of enterprise-supplier has positive influence on trust;

H3: Information sharing of enterprise-supplier has positive influence on commitment;

H4: Information sharing of enterprise-supplier has positive influence on innovation performance of enterprise.

\section{B. Communication}

Communication is the basis for the establishment of trust. Many scholars had conducted research on the relationship between communication and trust. When there were accurate and timely communication between them, the employees felt the superior can be trusted (Zhang Canquan, 2010) [3].

Anderson et al (1990) studied the results showed that, communication that have occurred was trust antecedent variables. From the enterprise's perspective can also be seen, communication that have occurred had a positive effect on trust. Wang Xiuting et al. (2012) through the research on influence of communication and trust of core enterprises on network innovation performance, they considered that communication can promote the enterprise to take innovative activities and had a vital role to improve the enterprise innovation performance, while it had a significant relationship between communication and trust.

Wang Xiuting et al. (2012) studied that, communication was the primary influence factor of cooperative behavior between the enterprises. Effective communication between enterprises can reduce the cost of development, accelerate the development speed and reduce development risk in the new product research and development process. Wang Longwei considered that information exchange and transfer was very important to improve organizational ability and accelerate the implementation of innovative products by enterprises. Zhang Shoukui considered that relations between the two sides for efficient communication can effectively reduce the opportunism behavior, so as to have a positive influence on the knowledge transfer between the enterprises. Nooteboom pointed that communication of enterprise can promote the exchange the important information within the network sharing and transfering, and it can bring the potential value of the relationship between the enterprises of capital embodied. Therefore, according to the above research, we can assume:

H5: Communication of enterprise-supplier has positive influence on trust;

H6: Communication of enterprise-supplier has positive influence on innovation performance of enterprise;

\section{Trust}

Trust as one of the important concepts of relational transaction, it allows trading partners to go beyond shortterm inequality or risk, focusing on or obtain the long-term profit (Constanza \&Saleh, 2011). Once the formation of trust, partnership will have a strong desire for the other party to promise more time, resources and energy to develop a continuous working relationship (Lv Hui, 2010). Trust affected commitment and long-term relationship and cooperation in order to complete the task and organizational performance effectively by enterprises (Shankar et al., 2009). Trust promoted commitment to maintain a relationship from a party to the other party (Song et al., 2008). Also trust increased the cooperation (Ye Fei et al., 2011; Zhang Xumei, 2011) [5]. Ramaseshan et al (2006) using the path model found that in the field of supply chain management, trust leaded to commitment. Inter organizational trust can enable enterprises to do the things they agreed to gain more confidence and commitment (Zand, 1972). High levels of inter organizational trust created the environment of a nonopportunistic behavior, and made more investment partners and committed relationship of commitment. Trust of Enterprise - Supplier Relationship provided a stable relationship using lower transaction costs, and brought good behavior. And it reduced the degree of contract law, so it was helpful to solve the problem of conflict between the two sides, promoting commitment (Sahay, 2003; Il Ryu, SoonHu So, Chulmo Koo, 2009). The relationship of trust and commitment has been widely studied, it is generally believed that trust has a significant positive effect on commitment. While Wang Qiang and storage Zhaofang (2012) studied that the effects of different types of trust for different types of commitment are different[6].

However, F. Xavier Molina-Morales et al (2011) studied that, from a strategic perspective, in the aspect of trust, over investment was harmful. Although some trust was in favor of tacit knowledge and the risk transfer, if the enterprises trust to much or invest too large in trust relationship which was little value to enterprises. It will allocate inappropriately for valuable resources and take unnecessary risks on potential negative effects of the enterprise's innovation performance[7].

In summary, we put forward the following hypothesis:

H7: Trust of enterprise-supplier has positive influence on commitment;

H8: Trust of enterprise-supplier has positive influence on innovation performance of enterprise;

\section{Commitment}

This paper considers commitment is a kind of attitude. We adopt Anderson and Weitz (1992) definition which enterprises eager to build a stable relationship with suppliers, and they are willing to make sacrifices in the short term to maintain this relationship, and have confident in the stability of this relationship [8].

In Morgan and Hunt (1994) study, they considered that commitment is the core relationship between enterprises and suppliers and foundation of the relationship between enterprises and suppliers. Due to the operation and management of the enterprises commitment to suppliers, its advantage lies in: first, for enterprises and suppliers, they maintain their long-term business relationship not 
only reduce transaction costs and increase the profits (Krause et al., 2007), but also can reduce the risk caused by the uncertainty, and improve the barrier, and prevent competitors from entering the target market (Meehan $\&$ Wright, 2011) [9]. Second, enterprises can full use investment, innovation and expertise of suppliers to focus on their own core competence, strategic influence on other activities. Zhang Xumei and Chen Wei (2012) divided the relationship of supply chain partnership into two dimensions of trust and commitment when they researched the relationship between supply chain partnership, knowledge exchange and innovation performance. According to the research results, commitment and innovation performance has a significant positive correlation [10].

In summary, we put forward the following hypothesis:

H9: Commitment of enterprise-supplier has positive influence on innovation performance of enterprise.

\section{E. Innovation performance}

We consider that enterprise innovation performance refers to the result of enterprises which lead new products and new technology invention into the market degree. And the product innovation performance and process innovation performance are as the two dimensions to measure the enterprise innovation performance. Therefore, we use five indicators which are the quantity of products per year, he number of new products accounted for the total number of enterprises of products, the product patent number for applying per year, the cycle of development of new products shortened and manufacturing costs and reduced the cost to measure the enterprise product innovation performance. We use the indicators which are the number of the development or introduction of new materials, the number of the development or introduction of new intermediate products, the number of the development or introduction of new components, the number of the development or introduction of new products' attribute, the number of the development or introduction of new equipment, the use of new energy to measure enterprise technological innovation performance .

According to the above research hypothesis, the theory conceptual model of this study is shown in Fig .1.

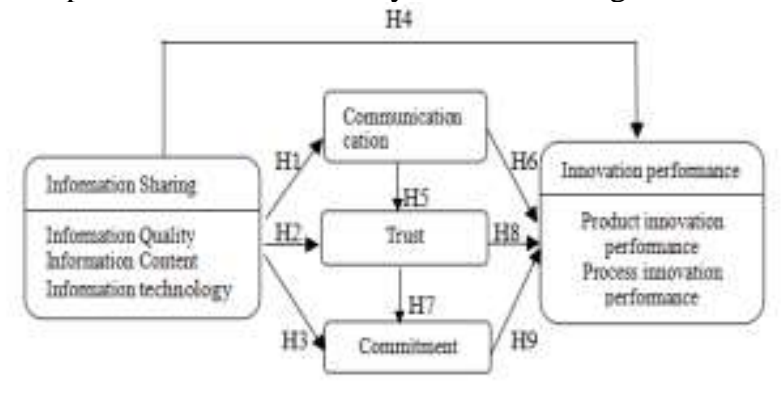

Figure 1. Conceptual Model

\section{RESEARCH AND DESIGN}

\section{A. The study sample}

In this study, according to research needs, we investigated in the manufacturing industry (including electric machinery manufacturing, electronics and communications equipment manufacturing, micro car manufacturing, heavy automobile manufacturing, heavy machinery manufacturing etc.). Therefore, we investigated in Shaanxi, Ningxia, Gansu, Sichuan, Shanxi, Henan, Jiangsu, Guangdong, Zhejiang, Hubei, Shanghai, Liaoning, Beijing and other provinces and cities[11]. The survey covered some representative cities of China western, central and eastern, including state-owned, private, joint ventures and other kinds of enterprises. The investigation objects and questionnaire respondents included the procurement personnel, project manager, senior managers of manufacturing enterprises. And the majority are economists, senior economists, engineers, senior engineers of manufacturing enterprises. There were 500 questionnaires we distributed and collected 360 questionnaires. There were 335 valid questionnaires, and the effective questionnaire recovery rate was $67 \%$.

\section{B. Variable measurement}

In this study to design questionnaire, we used Li Kete (Likert) 5 scale to measure variables with digital 1-5 to represent a survey by questionnaire in recognition of the extent of the items in the description of the problem. Among them, "1" represents "totally incompatible", "5" represents " fully compliant ". It strengthens the acceptance degree from " 1 " to " 5 " orderly.

On the measurement of independent variable information sharing part, we synthesize the research of scholar Monczka et al. (1998), Li and Lin (2006) [11], Forslund and Jonsson (2007), Miller, Li et al. (2006), combining with experts and manufacturing enterprises' interview to get the questions designing of this part. For the measuring the dependent variable innovation performance, we draw lessons from the domestic and foreign scholar Ma Hongjia (2011), Yun River (2012), Orhan. Mlek et al (2012), Peng Chan and Yang Ling (2009) , F. Xavier Molina-Morales et al (2011), combining with the expert and manufacturing enterprises' interview to get this part items. On the intermediary variable part, communication is based on the research of scholar Xiong Shiquan et al (2010) and Paulraj A et al (2008) and Liu Heng (2010), and combined with the manufacturing enterprises interview. Trust is based on the research of scholar Doney and Cannon (1997), combined with manufacturing enterprises interview. Commitment is based on the research of Morgan and Hunt (1994) [8] and Yi Liu etc. (2010), combined with manufacturing enterprise interview.

\section{THE RESULTS OF THE EMPIRICAL ANALYSIS}

\section{A. Analysis of reliability and validity}

This research use SPSS19.0 for reliability analysis, reliability test scale using the Cronbach value, the reliability of each variable value table 1 .

It is seen from table 1, Cronbach used in this study the scale of the variables for each dimension in more than 0.6, and the information sharing, scale overall Cronbach trust, commitment and innovation performance are at about 0.8 , show that the reliability of the scale by internal consistency test. 
TABLE I. SCALE RELIABILITY ANALYSIS

\begin{tabular}{|c|c|c|c|c|}
\hline Variable & Variable & $\begin{array}{c}\text { The } \\
\text { numb } \\
\text { er of } \\
\text { variab } \\
\text { les } \\
\end{array}$ & $\begin{array}{c}\text { Cronbach } \\
\alpha\end{array}$ & $\begin{array}{c}\text { Scale the } \\
\text { overallC } \\
\text { ronbach } \\
\alpha\end{array}$ \\
\hline \multirow{3}{*}{$\begin{array}{l}\text { Information } \\
\text { sharing }\end{array}$} & $\begin{array}{l}\text { Information } \\
\text { quality }\end{array}$ & 6 & 0.823 & \multirow{3}{*}{0.843} \\
\hline & $\begin{array}{l}\text { Information } \\
\text { content }\end{array}$ & 7 & 0.830 & \\
\hline & $\begin{array}{l}\text { Information } \\
\text { technology }\end{array}$ & 5 & 0.818 & \\
\hline \multicolumn{2}{|c|}{ Communication } & 6 & \multicolumn{2}{|l|}{0.869} \\
\hline \multicolumn{2}{|l|}{ Trust } & 5 & \multicolumn{2}{|l|}{0.827} \\
\hline \multicolumn{2}{|l|}{ Commitment } & 5 & \multicolumn{2}{|l|}{0.886} \\
\hline \multirow[b]{2}{*}{$\begin{array}{l}\text { Innovation } \\
\text { performance }\end{array}$} & $\begin{array}{l}\text { Product } \\
\text { innovation } \\
\text { performanc } \\
\text { e }\end{array}$ & 5 & 0.862 & \multirow[b]{2}{*}{0.889} \\
\hline & $\begin{array}{l}\text { Technologi } \\
\text { cal } \\
\text { innovation } \\
\text { performanc } \\
\text { e }\end{array}$ & 6 & 0.848 & \\
\hline
\end{tabular}

The validity test, using AMOS17.0 to sample the confirmatory factor analysis, scale the fit index analysis results as shown in table 2 .

TABLE II. SAMPLE VALIDITY ANALYSIS

\begin{tabular}{|l|l|l|l|l|l|l|l|}
\hline $\begin{array}{l}\text { Variabl } \\
\mathbf{e}\end{array}$ & $\boldsymbol{\chi}^{\mathbf{2}} / \boldsymbol{d} \boldsymbol{f}$ & $\begin{array}{l}\text { RM } \\
\text { SEA }\end{array}$ & $\begin{array}{l}\text { GF } \\
\text { I }\end{array}$ & $\begin{array}{l}\text { AG } \\
\text { FI }\end{array}$ & NFI & TLI & CFI \\
\hline $\begin{array}{l}\text { Informat } \\
\text { ion } \\
\text { sharing }\end{array}$ & 1.888 & $\begin{array}{l}0.08 \\
4\end{array}$ & $\begin{array}{l}0.89 \\
8\end{array}$ & $\begin{array}{l}0.85 \\
6\end{array}$ & 0.918 & 0.932 & 0.944 \\
\hline $\begin{array}{l}\text { Commun } \\
\text { ication }\end{array}$ & 1.746 & $\begin{array}{l}0.05 \\
4\end{array}$ & $\begin{array}{l}0.98 \\
7\end{array}$ & $\begin{array}{l}0.96 \\
2\end{array}$ & 0.972 & 0.975 & 0.987 \\
\hline Trust & 1.981 & $\begin{array}{l}0.08 \\
6\end{array}$ & $\begin{array}{l}0.94 \\
3\end{array}$ & $\begin{array}{l}0.90 \\
2\end{array}$ & 0.958 & 0.961 & 0.971 \\
\hline $\begin{array}{l}\text { commit } \\
\text { ment }\end{array}$ & 1.764 & $\begin{array}{l}0.08 \\
2\end{array}$ & $\begin{array}{l}0.93 \\
3\end{array}$ & $\begin{array}{l}0.88 \\
9\end{array}$ & 0.936 & 0.942 & 0.955 \\
\hline $\begin{array}{l}\text { Innovati } \\
\text { on } \\
\text { performa } \\
\text { nce }\end{array}$ & 1.468 & $\begin{array}{l}0.07 \\
4\end{array}$ & $\begin{array}{l}0.94 \\
1\end{array}$ & $\begin{array}{l}0.90 \\
4\end{array}$ & 0.943 & 0.954 & 0.965 \\
\hline
\end{tabular}

Seen from table 2, information sharing, trust, commitment and innovation performance are good fit of the model, has good validity.

\section{B. Correlation analysis}

This study uses SPSS19.0 to measure variable correlation

TABLE III. CORRELATION ANALYSIS (N=266)

\begin{tabular}{|l|l|l|l|l|l|}
\hline & $\begin{array}{c}\text { Infor } \\
\text { matio } \\
\mathbf{n} \\
\text { sharin } \\
\mathbf{g}\end{array}$ & $\begin{array}{c}\text { Commu- } \\
\text { nicate }\end{array}$ & Trust & Promise & $\begin{array}{c}\text { Innovati } \\
\text { on } \\
\text { perform } \\
\text { ance }\end{array}$ \\
\hline $\begin{array}{l}\text { Information } \\
\text { sharing }\end{array}$ & 1 & & & & \\
\hline $\begin{array}{l}\text { Communicatio } \\
\mathrm{n}\end{array}$ & $.547^{* *}$ & 1 & & & \\
\hline Trust & $.411^{* *}$ & $.529^{* *}$ & 1 & & \\
\hline Commitment & $.323^{* *}$ & $.430^{* *}$ & $.564^{* *}$ & 1 & \\
\hline $\begin{array}{l}\text { Innovation } \\
\text { performance }\end{array}$ & $.304^{* *}$ & $.532^{* *}$ & $.501^{* *}$ & $.562^{* *}$ & 1 \\
\hline$* *$ P significantly in $0.01, \mathrm{P} \& 1 \mathrm{lt} ; 0.01$ & & \\
\hline
\end{tabular}

analysis, as shown in table 3 .

As can be seen from table 3, there was a significant correlation between each variable information quality, information content, information technology and trust and commitment and innovation performance.

\section{Analysis of structural equation model}

Using AMOS17.0 to analyze the model of overall goodness of fit, get the fit indices of the model are shown in Table 4

TABLE IV. HYPOTHESIS PATH MODEL AND THE PATH MODEL CORRECTION

\begin{tabular}{|c|c|c|c|c|c|c|c|}
\hline & $\begin{array}{c}\boldsymbol{\chi 2} / \\
\text { df }\end{array}$ & $\begin{array}{c}\text { RMS } \\
\text { EA }\end{array}$ & GFI & $\begin{array}{c}\text { AGF } \\
\text { I }\end{array}$ & NFI & $\begin{array}{c}\text { TL } \\
\text { I }\end{array}$ & CFI \\
\hline $\begin{array}{c}\text { A } \\
\text { hypothe } \\
\text { sis } \\
\text { model }\end{array}$ & $\begin{array}{c}2.73 \\
1\end{array}$ & 0.081 & 0.840 & 0.80 & 0.858 & $\begin{array}{c}0.8 \\
91\end{array}$ & $\begin{array}{c}0.90 \\
4\end{array}$ \\
\hline $\begin{array}{c}\text { Correcti } \\
\text { on } \\
\text { model }\end{array}$ & $\begin{array}{c}2.53 \\
7\end{array}$ & 0.076 & 0.855 & 0.811 & 0.874 & 0.9 & 0.91 \\
9
\end{tabular}

TABLE V. EST RESULTS OF STRUCTURAL EQUATION MODEL OF THE CORRECTED PATH

\begin{tabular}{|c|c|c|c|c|c|c|}
\hline $\begin{array}{c}\text { Relationship } \\
\text { between the } \\
\text { path }\end{array}$ & $\begin{array}{c}\text { Standardized } \\
\text { path } \\
\text { coefficient }\end{array}$ & S.E. & C.R. & $\mathbf{P}$ & \begin{tabular}{|c|} 
The \\
corres \\
pondin \\
g \\
hypoth \\
esis \\
\end{tabular} & $\begin{array}{c}\text { Significa } \\
\text { nt } \\
\text { evaluatio } \\
n\end{array}$ \\
\hline $\begin{array}{c}\text { Information } \\
\text { sharing } \rightarrow \\
\text { Communication }\end{array}$ & .492 & .071 & 7.556 & $\begin{array}{l}* \\
* \\
*\end{array}$ & H1 & support \\
\hline $\begin{array}{c}\text { Information } \\
\text { sharing } \rightarrow \text { trust }\end{array}$ & .332 & .061 & 8.540 & $\begin{array}{l}0 \\
0 \\
1\end{array}$ & $\mathrm{H} 2$ & support \\
\hline $\begin{array}{c}\text { Information } \\
\text { sharing } \rightarrow \\
\text { commitment }\end{array}$ & .457 & .004 & 8.560 & $\begin{array}{l} \\
* \\
*\end{array}$ & H3 & support \\
\hline $\begin{array}{l}\text { Information } \\
\text { sharing } \rightarrow \\
\text { Innovation } \\
\text { performance }\end{array}$ & .623 & .034 & 9.381 & $\begin{array}{l}* \\
* \\
*\end{array}$ & $\mathrm{H} 4$ & support \\
\hline $\begin{array}{c}\text { communication } \\
\text { trust }\end{array}$ & .426 & .093 & $\begin{array}{c}11.81 \\
6\end{array}$ & $\begin{array}{l}* \\
* \\
*\end{array}$ & H5 & support \\
\hline $\begin{array}{c}\text { Communication } \\
\rightarrow \text { Innovation } \\
\text { performance }\end{array}$ & .604 & .083 & $\begin{array}{c}11.14 \\
9\end{array}$ & $\begin{array}{l}* \\
* \\
*\end{array}$ & H6 & support \\
\hline $\begin{array}{c}\text { trust } \rightarrow \text { Innovation } \\
\text { performance }\end{array}$ & .502 & .058 & 8.988 & $\begin{array}{l}* \\
* \\
*\end{array}$ & $\mathrm{H} 7$ & support \\
\hline $\begin{array}{c}\text { trust } \rightarrow \\
\text { commitment }\end{array}$ & -.403 & .078 & $\begin{array}{c}- \\
7.358 \\
\end{array}$ & $\begin{array}{l}1 \\
3 \\
2\end{array}$ & H8 & $\begin{array}{l}\text { does not } \\
\text { support }\end{array}$ \\
\hline $\begin{array}{c}\text { commitment } \rightarrow \\
\text { Innovation } \\
\text { performance }\end{array}$ & .548 & .057 & $\begin{array}{c}11.18 \\
0\end{array}$ & $\begin{array}{l}\text { * } \\
* \\
*\end{array}$ & H9 & support \\
\hline
\end{tabular}

As can be seen from Table 4, assuming that the model $\chi 2 / \mathrm{df}=2.731<3$, RMSEA $=0.081<0.1$, GFI $=0.840$ $<0.8, \mathrm{AGFI}=0.80, \mathrm{NFI}=0.858>0.80, \mathrm{TLI}=0.891<0.90$, $\mathrm{CFI}=0.904>0.80$, it can be seen that the model does not 
fit index GFI and TLI acceptable range. After the model was revised and adjusted, corrected model fit indices of $\chi 2$ $/ \mathrm{df}=2.537<3, \mathrm{RMSEA}=0.076<0.1, \mathrm{GFI}=0.855>0.85$, AGFI $=0.811>0.80, \mathrm{NFI}=0.874>0.80, \mathrm{TLI}=0.903>$ $0.90, \mathrm{CFI}=0.919>0.80$, the indicators show that the model has reached an acceptable range, the model has a good fit degrees.

\section{Hypothesis testing}

The initial model was modified to obtain the path parameter estimation function, as shown in table 5 .

As can be seen from table 5 of $\mathrm{H} 1, \mathrm{H} 2, \mathrm{H} 3, \mathrm{H} 4, \mathrm{H} 5$, $\mathrm{H} 6, \mathrm{H} 7$ and $\mathrm{H} 9$ has been verified, and the $\mathrm{H} 8$ has not been verified.

Thus obtains this article the hypothesis test results as shown in table 6.

TABLE VI. REGRESSION PATH INSPECTION RESULTS OF STRUCTURAL EQUATION MODEL

\begin{tabular}{|c|c|c|}
\hline Hypothesis & Assuming content & Result \\
\hline H1 & $\begin{array}{l}\text { Enterprise and supplier of } \\
\text { information sharing has positive } \\
\text { influence on communication; }\end{array}$ & support \\
\hline $\mathrm{H} 2$ & $\begin{array}{c}\text { Enterprise and supplier of } \\
\text { information sharing has positive } \\
\text { influence on trust; }\end{array}$ & support \\
\hline H3 & $\begin{array}{l}\text { Enterprise and supplier of } \\
\text { information sharing has positive } \\
\text { influence on commitment; }\end{array}$ & support \\
\hline $\mathrm{H} 4$ & $\begin{array}{lcc}\text { Enterprise } & \text { and supplier of } \\
\text { information } & \text { sharing on the } \\
\text { enterprises } & \text { have a positive } \\
\text { influence } & \text { on } & \text { innovation } \\
\text { performance; } & & \end{array}$ & support \\
\hline H5 & $\begin{array}{lcc}\begin{array}{l}\text { Enterprise } \\
\text { communication } \\
\text { effect on trust; }\end{array} & \text { have a } & \text { posplitive } \\
\end{array}$ & support \\
\hline H6 & $\begin{array}{l}\text { Enterprise } \\
\text { communication have a positive } \\
\text { impact on enterprises innovation } \\
\text { performance; }\end{array}$ & support \\
\hline H7 & $\begin{array}{l}\text { Enterprise supplier trust has a } \\
\text { positive effect on commitment; }\end{array}$ & support \\
\hline H8 & $\begin{array}{l}\text { Enterprise supplier trust has a } \\
\text { positive impact on enterprises } \\
\text { innovation performance; }\end{array}$ & do not support \\
\hline H9 & $\begin{array}{l}\text { Enterprise supplier commitment } \\
\text { has a positive impact on enterprises } \\
\text { innovation performance. }\end{array}$ & support \\
\hline
\end{tabular}

\section{RESULTS AND DISCUSSION}

Through empirical research, the results show that, between the enterprise and the supplier information sharing has a direct positive effect on innovation performance of enterprises, communication between them, trust and commitment have significant positive effect, which is explained by the advanced information technology to share high quality information of value between the enterprise and the supplier, can to promote the communication between the two sides, deepen mutual trust, so as to promote the two sides in order to maintain this relationship to a compromise with each other; enterprise supplier communication and commitment and enterprise innovation performance significantly positive correlation, but the relationship between trust and enterprise innovation performance is not significant; this shows that good and communication among providers and commitment, can promote enterprise of innovative activities, improve innovation performance; therefore, information sharing can also have an indirect influence on innovation performance through communication and commitment.

\section{ACKNOWLEDGMENT}

This thesis is funded by science and technology project of Xi'an City(SF1408-3).

\section{REFERENCES}

[1] Ma H.J.. An Empirical Study on Flexibility and Innovation Performance in IT System $[\mathrm{J}]$. Journal of Information, 2011,30(4):76-80

[2] Cheng H.C., Chen M.C., Mao C.K.. The evolutionary process and collaboration in supply chains, Industrial Management \& Data Systems, 2010, 110 (3):453-474.

[3] Zhang C.Q.. Study on the influence mechanism of commitment to change communication [D]. Zhejiang University,2010.

[4] Wang X.T., Du H.B., Jiang C. The Study of Core Enterprise's Impact on Innovation Performance in Technological Innovation Network: The Intermediary Role of Communication and Trust $[\mathrm{J}]$ Science of Science and Management of S.\&T., 2012,33(12):37-44.

[5] Ye F, Wu J, Lv H. Mechanism of Action Research of Individual Relationship among executives on Supplier Information sharing: Based on Inter-organizational Trust [J]. Science of Science and Management of S.\& T.,2011,32(6):140-149.

[6] Wang L.W., Yeung J.H.Y., Zhang M.. The impact of trust and contract on innovation performance: The moderating role of environmental uncertainty $[\mathrm{J}]$. Int. J. Production Economics,2011,134:114-122.

[7] Wang Q, Chu Z.F.. The Impact of Dependence, Trust, and Commitment on Third Party Logistics Integration and Performance: An Empirical Study from China[J]. China Soft Science, 2012,12:133-145.

[8] Morgan R. M, Hunt S. D. The Commitment-Trust Theory of Relationship Marketing[J]. Journal of Marketing, 1994,58(3):20-38.

[9] Meehan J., Wright G.H. Power priorities: A buyer-seller comparison of areas of influence[J]. Journal of Purchasing and Supply Management, 2011, 17(1): 32-41.

[10] Chad W.A., Susan L. Golicic. Evaluating buyer-supplier relationship-performance spirals: A longitudinal study[J].Journal of Operations Management, 2010,28:87-100.

[11] Zhang X.M., Chen W. An Empirical Study on Relationship between Supply Chain Partnership and Innovation Performance from the Perspective of Knowledge Trading [J]. Journal of Business Economics,2012,2:34-45. 